\title{
FROM CO-DESIGN TO CO-EDUCATION: A COMMUNITY COLLABORATION STUDY CASE FOR DESIGN EDUCATION
}

\author{
Duan WU1, Yin SHI and Yang LIU ${ }^{3}$ \\ ${ }^{1}$ College of Design \& Innovation, Tongji University, Shanghai Institute of Design and \\ Innovation \\ ${ }^{2}$ College of Design \& Innovation, Tongji University \\ ${ }^{3}$ Institute of Shanghai Architectural Design \& Research
}

\begin{abstract}
Design education aims to serve environmental, technological and societal changes and challenges. While evidence suggests a worldwide increase of cross-disciplinary working as partnerships transcend the confines of predefined and historical silos. Thus, the premise of this paper is that the field of design needs to engage design students more regularly with community collaboration and broaden the application of design skills into more diverse arenas of creative problem solving.

Co-design activities are emphasised as an approach which is focused on processes and procedures of design, not just a design style. In this case, as part of an experiment teaching project in Tongji University, College of Design \& Innovation undergraduate programme, we tried to bridge co-design methods with design education process in environmental design studio course, in which the second-year students are required to be aware of design process and the ability of cross-disciplinary working and collaboration. This paper will introduce the course syllabus and processes on how to involve in co-design method and community collaboration and will also examines how those pedagogical approaches has been applied in three different school years: 2016, 2018 and 2019. It will detail the different approaches each year have used to construct learning opportunities, along with a profile of the participants, resources and methods utilized. The findings will provide a structure to compare and contrast different approaches used in different years in order to draw conclusions regarding outcomes. The research is still in its early stage, while aims to raise discussion about how to educate students who can effectively tackle the multidisciplinary wicked challenges of the future.
\end{abstract}

\section{Keywords: Design education, co-design, community collaboration, pedagogical research}

\section{BACKGROUND}

Evidence suggests a worldwide increase of cross-disciplinary working as partnerships transcend the confines of predefined and historical silos. The challenges of this era are no longer defined in single discipline or individual effort. Design education aims to 'serve environmental, technological and societal changes and challenges. Thus, according to the challenges, we need new studies to investigate and explore the issues involved in methods of design education as well as methods of practice. (Lou YQ.2013 ) We need an innovative and inclusive educational ecosystem that will enable the application of new knowledge and methods to generate social and economic changes.

It is a fact that design research, as a way of interpreting and producing knowledge on the reality, has enhanced, in the last decades, by applying a certain range of tools and practices that currently are recognized under the umbrella of co-design. Today co-design is understood as the transversal approach to lead design research into different design domains of application, from user driven projects conducted by design firms to more open innovation projects lead by companies or designers that want to collaborate with their users in innovation generation. (Francesca Rizzo. 2011)

Co-design activities are emphasized as an approach which is focused on processes and procedures of design, instead of just a design style or physical outcome. The activities are usually applied to enhance idea generation and strategic concept design, which are benefit and characterized by the participation of non-designer's stakeholders and lead by designers. 
With this background, we begin to experiment in a proactive way in design education, connecting and sharing experiments through educational practice, improving co-design methods and tools that can apply in a variety of educational courses contexts. The impacts then be measured not by individual student's design drawing skills, but by their abilities to solve problem in the more complex context and the abilities of collaboration in a wide range of situations.

In this case, supported by the Pedagogical Research Projects in Tongji University, we tried to bridge codesign methods with design education process in environmental design studio course (1), in which the second-year students are trained to be aware of basic design skills and process and also capable of interacting with and understanding specialists from a wide range of disciplines and functional areas.

The environmental design studio course (1) provides interdisciplinary design training and education to students at Tongji University College of Design and Innovation, including its international and exchange students.

The idea of this research is to create an alternative educational opportunity that more regularly engage design students with community collaboration and broaden the application of design skills into more diverse arenas of creative problem solving. There is nothing more challenging to the students than placing them into a real world context where it is impossible to work without immersing with the users and the context in order to move on to idea generation. And there is no more challenging context to understand than the social context in community regeneration.

\section{CASE INTRODUCTIONS}

\subsection{Curriculum}

Contact Hours: 136 hours (17 weeks, 8 hours/week)

Major: Industrial Design, Environmental Design

Assessment: Course work and assignments

Prerequisite: Design Basics

Students: maximum 36 (divide into 6-8 groups)

\section{Course Objective and Requirement:}

The course is the first specialized design studio for the students of Environmental Design Programme. The students are required to synthesize the various knowledge and skills, to use holistic, human-centred and sustainable way to create and enable a sustainable life-space, including experience, communication and space that facilitate interaction of humans with their surroundings. Based on "problem-based" learning approach, the course will involve projects with real contexts. The topics of the studio will focus on today's real-world challenges especially community renew issues. At the same time, the course encourages the collaboration with industries, government or community in the critical and prospective view.

The overall objective of this course is helping students have a substantial increase in terms of in-depth understanding of the programme, ability of design process, design methods, and skills. The course helps students:

a) to better understand what basic design process is, including define problem, collect information, brainstorm $\&$ analyse, develop prototype, test ideas and get feedback, improve design. The course will evaluate whether there is a compelling research, methods and processes.

b) to stress both the holistic skills and the design outcome. They need to seek their answers in a broad and interdisciplinary context, address its ecological, societal and commercial impact, as well as the relationship with other disciplines.

c) to present their outcome. The course will focus on training students' holistic communication skills. The course will organize an exhibition as a part of the final presentation and invite guests from industry, community and university.

The course is structured in five modules:

1. Lectures and Seminars 1 (2 weeks)

Based on the selected project, curriculum and schedule, the course will have selected lectures, mainly to introduce the relevant theory, research and design skills, and expertise related to the subject and so on.

2. Workshop 1 (4 weeks) (group work) 
Project related with basic place making and communication. Indoor or outdoor mall scale design such as street booth, pop-up exhibition booth etc.

3. Lectures and Seminars 2 (2 weeks)

Based on the selected project, curriculum and schedule, the course will have selected lectures, mainly to introduce the relevant theory, research and design skills, and expertise related to the subject and so on.

4. Workshop 2 (8 weeks) (group work)

Project in the real world with real community users and needs such as small-scale community renew. With more complex context and stakeholders to communicate and research, students will need to use more broad knowledge and skills to solve problem. The selected design works need to be implemented. 5. Exhibition and Presentation (1 week)

At the end of the course, an exhibition and seminar will be organized for experience exchanging and sharing.

\subsection{Methodology}

Rationale for comparison:

These three year courses are sharing the same curriculum in many ways in: students background, course structure, objective and teaching team. The differences are mostly in the third and fourth modules about how to choose the working project. These similarities and differences offer a unique opportunity to compare approaches to teaching.

The courses' results are distinct as a reflection of three years different projects, scope and working requirements:

Table 1. The comparison of Module 4 project in three years

\begin{tabular}{|c|c|c|c|c|c|}
\hline year & $\begin{array}{l}\text { Project of } \\
\text { module } 4\end{array}$ & Stakeholders & \multicolumn{2}{|c|}{ Methods } & $\begin{array}{l}\text { Real-life } \\
\text { exposure }\end{array}$ \\
\hline \multirow{3}{*}{$\begin{array}{c}2016 \\
33 \text { students }\end{array}$} & \multirow{3}{*}{$\begin{array}{l}\text { Space renew in } \\
\text { College } \\
\text { building }\end{array}$} & \multirow{3}{*}{$\begin{array}{c}\text {-Students } \\
\text {-Teachers } \\
\text {-College staff } \\
\text {-visitors }\end{array}$} & observation & personas & \multirow{3}{*}{$10 \%$} \\
\hline & & & survey & scenarios & \\
\hline & & & interview & quick prototype & \\
\hline \multirow{5}{*}{$\begin{array}{c}2018 \\
32 \text { students }\end{array}$} & \multirow{5}{*}{$\begin{array}{c}\text { Residential } \\
\text { Building Public } \\
\text { Space Renew in } \\
\text { Siping } \\
\text { Community }\end{array}$} & \multirow{5}{*}{$\begin{array}{c}\text {-Residents } \\
\text {-Government } \\
\text {-Visitors } \\
\text {-Community } \\
\text { workers }\end{array}$} & observation & personas & \multirow{5}{*}{$30 \%$} \\
\hline & & & survey & interview & \\
\hline & & & storyboard & scenarios & \\
\hline & & & $\begin{array}{l}\text { quick } \\
\text { prototype }\end{array}$ & $\begin{array}{l}\text { user journey } \\
\text { map }\end{array}$ & \\
\hline & & & $\begin{array}{l}\text { co-design } \\
\text { workshop }\end{array}$ & Implementation & \\
\hline \multirow{6}{*}{$\begin{array}{c}2019 \\
34 \text { students }\end{array}$} & \multirow{6}{*}{$\begin{array}{l}\text { Space Renew in } \\
\text { Siping } \\
\text { Community } \\
\text { (students should } \\
\text { define their own } \\
\text { design location } \\
\text { and scope) }\end{array}$} & \multirow{6}{*}{$\begin{array}{l}\text {-Residents } \\
\text {-Government } \\
\text {-Visitors } \\
\text {-Community } \\
\text { workers }\end{array}$} & observation & personas & \multirow{6}{*}{$50 \%$} \\
\hline & & & survey & interview & \\
\hline & & & storyboard & scenarios & \\
\hline & & & $\begin{array}{l}\text { user journey } \\
\text { map }\end{array}$ & quick prototype & \\
\hline & & & $\begin{array}{l}\text { co-design } \\
\text { workshop }\end{array}$ & $\begin{array}{l}\text { solution } \\
\text { evaluation }\end{array}$ & \\
\hline & & & $\begin{array}{l}\text { community } \\
\text { meeting }\end{array}$ & Implementation & \\
\hline
\end{tabular}

Through the process observation and the questionnaire of students, we find out that some of the methods had significant effect on the course objective which involved the "real" stakeholders in the design education process. The following methods or steps exposed our students to the real life and through which the students got increased skill on collaboration, communication and understanding of the real world changelings, while at the same time active young students and fresh mind brought the community (the Siping community is a typical aging community in Shanghai) change and energy. With this background, education methods and process transferred into a double side benefit way, after reviewing the whole feedback of the case, we turned out to call it Co-Education process. 
-Field Visit and User Observations Database

The first field visit and user observation are usually frustrated to the students. Lack of understanding of the project, most of the residents refuse to collaborate and even oppose to them. For the students, lack of experience to work with real user, they even do not know how to start communication with strangers. This experience helped students to think and learn from real life, to face the real world challenging that may never appears on a textbook.

-User Interview

With the help from teaching ream, our students had progress on user interview part. They start to think how to work with different stakeholders and how to encourage them to engage more into the project. It became a spontaneous learning process, and it is more effective than imparted from teachers.

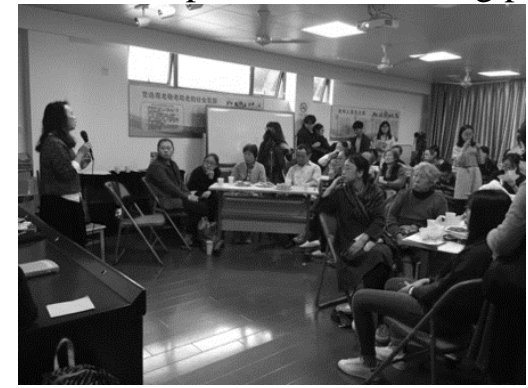

Figure 1.community meeting

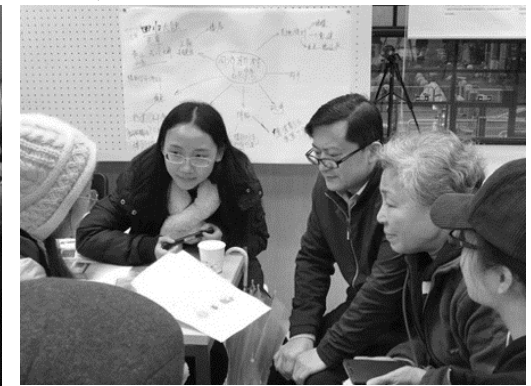

Figure 2.3.Co-design workshops

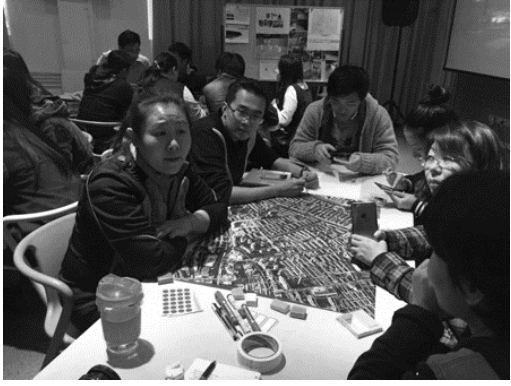

8

\section{-Community Meeting}

We encourage students to invite their target user to participate in the meeting, in which teachers will introduce the overall project and answer questions from the residents. Students and their users sit in group and have activities to warm up and build trust.

-Co-design Workshop

Among all the methods used in the teaching process, the co-design workshop addressed with deviation that may arising in both the design and educational process. In the year 2018 and 2019 module 4, We organized expert designers who dedicated in community social innovation design, government managers, residents and students, to carry out co-design workshops several times with two main purposes. One was to enhance idea generation and strategic concept design also inspire design process by communication with different stakeholders, and the other was to help students training the ability of trans-disciplinary working and thinking in more diverse perspective.

\section{-Implementation}

From the above processes, residents understood more about the design objective, got familiar with their young designers, some of them even involved in the decision-making process. Most of the users showed supportive to the implementing process and even tried to help in many ways. It was touching that some of them provided water and fruit and even invited students to have dinner in their home. This experience helped students understand more about the core of co-design "from design for people, to design with people", and in the questionnaire some students said at the moment they felt the value of design.

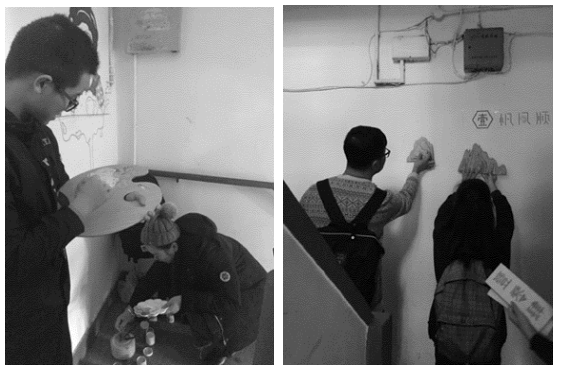

Figure 4. the implementation process

\subsection{Results}

As a result, the course not only encourages collaboration between students, but also closely relates to emerging real-world challenges.

Real project practice allows undergraduates to obtain knowledge from more than a single discipline with a sufficiently broad perspective (Hobday et al. 2011). Embedded co-design methods encouraged students to communicate and get quick feedback from the real stakeholders. We see this as a viable experiment that is able to respond to Don Norman's criticism on general design education - trying to encounter complex and comprehensive challenges from the real world but failing to do so due to a lack of necessary knowledge and skills (Norman, 2010). In its essence, the experimental educational case we envision here is, using co-design methods to break the rigid barriers between disciplines, and integrating 
knowledge and skills at different levels to satisfy the needs and to realize the values arising from this changing world (Buchanan, 1992).

Using the survey results, we identified two notions that reflected outcomes from the class that we felt could be emphasized to the course research:

Table 2. The comparison of feedback from students in three years

\begin{tabular}{|c|c|c|c|}
\hline \multirow[b]{2}{*}{ year } & \multicolumn{2}{|c|}{ Feedback questionnaire from the students } & \multirow{2}{*}{$\begin{array}{c}\text { Course } \\
\text { rating } \\
(100)\end{array}$} \\
\hline & positive & negative & \\
\hline 2016 & $\begin{array}{l}\text {-Learned how to think more open- } \\
\text { minded. } \\
\text {-Diversity, group work. } \\
\text {-Time management. } \\
\text {-Idea generation. }\end{array}$ & $\begin{array}{l}\text {-Hard to work in team } \\
\text {-lack of design analysis methods }\end{array}$ & 87.5 \\
\hline 2018 & $\begin{array}{l}\text {-The chance to work with real users. } \\
\text {-The way we work as team to find } \\
\text { solutions and generate ideas. } \\
\text {-Set of creation and co-design. } \\
\text {-Flexibility. } \\
\text {-Very challenging in the } 2^{\text {nd }} \text { project. } \\
\text {-Design thinking and methods. }\end{array}$ & $\begin{array}{l}\text {-Very challenging in the } \\
\text { complementation phase. } \\
\text {-Frustrated while communicating } \\
\text { with some residents. }\end{array}$ & 90.7 \\
\hline 2019 & $\begin{array}{l}\text {-Real practice opportunity. } \\
\text {-Confidence communion. } \\
\text {-Diversity, group work. } \\
\text {-Negotiation skills. } \\
\text {-Time management. } \\
\text {-Solid ability of co-working. } \\
\text {-Idea generation. } \\
\text {-motivation }\end{array}$ & $\begin{array}{l}\text {-Consuming a great deal of time } \\
\text { outside class. } \\
\text {-Lack of complementation } \\
\text { knowledge. } \\
\text {-Hard to define and narrow down } \\
\text { the problem. }\end{array}$ & 89.9 \\
\hline
\end{tabular}

\section{FINDINGS}

According to students' free responses to university administered surveys, there were increasing positive feedback among students who participated in the course among three years. However, the average overall course rating slightly decreased in year 2019, and students spent more time on their projects outside of class time than students in previous versions of the course.

\subsection{Teamwork}

Even though our design students do not have teamwork experience in previous courses, and are not trained to have teamwork skills, it showed that co-design working process with community residents and diverse methods using helps the students to response more active when facing collaboration problems. "During the community project, I turned to find out that the tools help us to communicate with the community residents, could also work in our team members. They are great methods that helps to facilitate and avoid useless struggle in the process." One student said after the course. This is also coupled with observational experience of watching student teams during the three years in the process. They tend to be willing to take initiative and jump into the more open-ended process.

\subsection{Working and learning location}

Location for the module 4 projects of learning experiences is critical. In school, students feel like students, in the off-campus community spaces, they feel and behave more professionally. This helped the students to be more focused and have a sense of mission. It seems that standard classroom space is not conducive to creating these types of learning experiences.

\subsection{Soft skills}

Some of the greatest benefits for students participating in these co-design workshops are soft skills that are more challenging to measure. It is clear that this type of experience working with the real world users presents best practices to prepare students for real teamwork in the future environment, as they are working across significant disciplinary boundaries. As in the case, students express being more empowered to take less-defined challenges such as module 4. Being connected to real-world challenges, 
they see themselves as agents of change in the world and are motivated to participate. Showed from the teachers' observation and students' feedback, students' soft skills for working with others, dealing with complex context, and presenting through are clearly enhanced.

\subsection{Values}

The focus of these course experiences is to better prepare students for the changing future world, not to only provide professional skills. Meanwhile, in this course project experience, the real value is both for the students and the community. Communities get significant value from the work that students do, though it may not be complete or fully refined in the end. However, the co-design process activates the residents and other community members to think about their own environments' problems, helped framing and solving community issues not only related with the course defined project scope. And students, beside teamwork and soft skills, develop their professional skills in a hybrid academicprofessional environment and more willingness to take risks.

Moreover, those values are true for students as well as faculty. Faculty team step out of their comfort zones and expend their areas of expertise during the process.

\section{CONCLUSIONS}

This paper is a novel approach to embed co-working methods in design education process and at a theoretical level as a very early step. Appropriately defining the project challenge and desired outcomes is critical to the education outcome. From experience in year 2019, leaving the project too broad, and expecting student teams to define their own challenge, tends to get solutions complicated and hard to push into the implementation phase. On the other extreme in year 2016, being too narrow with the problem defined denies students the opportunity to discover and define their own challenges and decreases intrinsic motivation among students. While the research has strong institutional support and a refined efficient structure and is expected to continue in the coming years. The joint team will continue to explore the educational offering for the students in the diversified group with new challenges from the economy, society and technology.

\section{REFERENCES}

[1] Lou Yongqi, Fan Fei, and M.A. Jin. Mission D, an Interdisciplinary Innovation and Venture Programme at Tongji University. Creating Innovation Leaders. 2016, 201-213

[2] Francesca Rizzo. Co-design versus User Centred Design: Framing the differences. Notes on Doctoral Research in Design-Contributions from the Politecnico di Milano. Francoangeli 2011. 125-126

[3] Buchanan R. Wicked Problems in Design Thinking. Design Issues 8(2)1992:5-21

[4] Norman, D. Why Design Education Must Change. Retrieved September 28, 2013, from Core77, Available: http://www.core77.com/blog/columns/why design education must change_17993.asp

[5] Zupan B, Nabergoj AS. Developing Design Thinking Skills in Entrepreneurship Education. Leading Through Design. Boston: Design Management Institute. 2012

[6] Fan, F. et al. Using Living Labs Methodology to Design Entrepreneurship Education Programme in China: The case of a Pilot Minor at Tongji University in collaboration with Aalto University. ENoLL OpenLivingLab Days 2014 Conference Proceedings. Belgium

[7] Lou Yongqi, The Idea of Environmental Revisited, Design Issues 35(1).2019

[8] Apsan A. Re-imagining Participatory Design: Reflecting on the ASF-UK Change by Design Methodology. Design Issues, 2016, 32(3), 98-111. 